University of Wyoming College of Law

Law Archive of Wyoming Scholarship

$1-1-2020$

\title{
Post-Traumatic Stress Disorder (PTSD) Coverage and other Expanding Benefit Changes in the Workers' Compensation Insurance Marketplace: Academic Legal Perspective
}

Michael C. Duff

University of Wyoming College of Law, michael.duff@slu.edu

Follow this and additional works at: https://scholarship.law.uwyo.edu/faculty_articles

\section{Recommended Citation}

Duff, Michael C., "Post-Traumatic Stress Disorder (PTSD) Coverage and other Expanding Benefit Changes in the Workers' Compensation Insurance Marketplace: Academic Legal Perspective" (2020). Faculty Articles. 74.

https://scholarship.law.uwyo.edu/faculty_articles/74

This Article is brought to you for free and open access by the UW College of Law Faculty Scholarship at Law Archive of Wyoming Scholarship. It has been accepted for inclusion in Faculty Articles by an authorized administrator of Law Archive of Wyoming Scholarship. 


\section{Post-Traumatic Stress Disorder (PTSD) Coverage and other}

Expanding Benefit Changes in the Workers' Compensation Insurance Marketplace:

\section{Academic Legal Perspective}

Panel Discussion at Annual Meeting of the National Council of Insurance Legislators

December 12, 2019

Professor Michael C. Duff

University of Wyoming College of Wyoming College of Law 
Firefighter Presumptions and PTSD Coverage

NCOIL Annual Meeting, December 12, 2019

Remarks of Professor Duff

\section{Introduction}

Whenever policy makers consider expanding workers' compensation coverage there is concern expressed that expansion risks converting workers' compensation into general accident or health insurance. It is easy to understand why policy uneasiness may emerge when assessing expanded coverage of arguably work-related disabilities like post-traumatic stress disorder (PTSD), or when debating the option of adopting relaxed workers' compensation causation standards-"Firefighter Presumptions"-in connection with diseases sustained by law enforcement officials, safety personnel, and first responders. After all, expanded coverage means expanded costs (and, of course, the need to insure against those costs). But workers' compensation has had a long history of fundamental expansion since its inception over a century ago, often to the point where one can no longer imagine the expansion as not being originally part of the system. Often under the surface, workers' compensation expansion is tracking similar expansion in tort liability, and the workers' compensation expansion reflects a perceived need for enhanced tort immunity - though many involved in the debate may not be aware of this dynamic. In other words, increases in workers' compensation costs are constantly being weighed against the potential for increased tort liability.

To take one broad historical example, many observers of workers' compensation may be unaware that, in the earliest versions of the American workers' compensation statutes, circa 1911, no provision at all was made for payment of ongoing medical care in connection with work-related injuries. At that time, workers' compensation medical benefits were limited to post-injury first aid at the workplace, and perhaps initial medical treatment for, at most, 90 days. ${ }^{1}$ The first United Kingdom workers' compensation statute (of 1897, as amended in 1906-the progenitor of most American statutes ${ }^{2}$ ) did not cover ongoing medical benefits: something akin to national health care for workers was about to arrive on the scene in the U.K. in $1911 .^{3}$ (The other early workers' compensation model, German workers' compensation, established in about 1884, was similarly part of a much broader universal health care insurance system in which work-related medical costs and indemnity payments merged into a broad social insurance structure). ${ }^{4}$ The point is that American statutes had to expand to cover ongoing medical treatment for work-related injuries. Few in 2019, however, think of medical coverage for work-related injuries as an "expansion" of the original idea of workers' compensation. Workers' compensation "had" to expand because, if American workers' compensation statutes had not covered the expense of ongoing medical treatment for work-related injuries, that expense would have to have been pursued by workers in tort litigation, with all the expense that process has always entailed. American stakeholders preferred expanded workers' compensation and tort immunity to expanded tort liability.

Along similar lines, many readers may know that workers' compensation was originally limited to coverage of extrahazardous employment. One reason for the limitation was that it was not known by state legislatures until 1917 whether the United States Supreme Court would uphold on constitutional grounds a version of the Grand Bargain that included non-hazardous employment. Another reason for states deciding initially to cover only extrahazardous employment was that it was there that the need for workers' compensation coverage was most acutely felt. ${ }^{5}$ 
(Necessity is often the mother of invention). Eventually, the U.S. Supreme Court very broadly authorized the Grand Bargain - the historic "quid pro quo" of workers' compensation benefits for tort damages (and defenses). ${ }^{6}$ The High-Court authorization solved major problems, but created new ones. Now that states possessed a more-or-less legal blank slate on which to write workers' compensation law (albeit with some very broad boundaries), they were placed in a position of having to flesh out exactly what the quid pro quo should entail. But states had no hesitation expanding workers' compensation coverage from solely extrahazardous employment to most employment. ${ }^{7}$ And, again, from the perspective of employers, with the costs of workers' compensation expansion came (and comes) the benefits of expanded tort immunity. There were, of course, other statutory beneficiaries: workers relieved of the time and expense of pursuing tort litigation (to say nothing of workers who would have had no viable tort claims at all); and societyat-large, which benefitted from having the costs of workplace injury shifted to producing sectors of the economy (and away from broad taxpayer subsidization), and which also benefitted from safer workplaces generally.

Before discussing the question of relaxed disease causation for firefighters, and expansion of workers' compensation to PTSD, it is necessary to review some preliminary workers' compensation legal-doctrinal problems associated with occupational disease and with "mental injury" claims.

\section{Injury by Accident Arising Out of Employment}

At the most basic level, the legal problem with covering any disease under workers' compensation (including diseases disproportionately suffered by firefighters/law enforcement officials/first responders) is that disease (i) often is not the product of a specific "accident;", and (ii) often does not clearly "arise out of" employment. Most of the earliest American workers' compensation statutes defined covered injuries as those occurring "by accident arising out of and in the course of' employment. ${ }^{9}$ This traditional workers' compensation causal connection/coverage formulation - which is still followed in most states-created (and continues to create) legal issues. Without thinking too hard about the matter, one can immediately see that the "accident" component of the formula ${ }^{10}$ does not fit comfortably with injuries that develop over time - for example, a gradually deteriorating lower back - nor does the idea of "accident" fit well with the idea of occupational diseases contracted over the course of a working career. Despite the uncomfortable fit, Massachusetts covered occupational diseases under its workers' compensation act virtually from its inception in $1911 .{ }^{11}$ California and Wisconsin began covering occupational diseases in 1917, and by 1954 all but two states covered occupational disease. ${ }^{12}$ Why all the coverage despite the lack of an accident? No doubt part of the reason had to do with a liberal, flexible construction of workers' compensation statutes: in doubtful cases lean in favor of coverage so that the statute may accomplish its "beneficent purposes." ${ }^{13}$ But a large part of the story was that workers' compensation expansion simultaneously expanded tort immunity, which follows as a matter of law for employers participating in the system. 
Another doctrinal, causal-connection problem with the traditional workers' compensation coverage formula has to do with disease "arising out of"-or being causally related toemployment. A comparison between tort causation and workers' compensation causation may be helpful in understanding the problem. Under traditional tort law/personal injury conceptions of causation, a defendant is the cause of a plaintiff's harm when, "but for" the defendant's negligence, the plaintiff would not have been injured (the plaintiff's injury must also generally have been foreseeable by the defendant). Workers' compensation legal causation standards ask a different question. Did the injury "arise out of" the employment? Under the majority rule, the focus is on whether the workplace "increased the risk" of an employee being injured. Under the minority rule, the "positional risk" rule, the focus is on whether the employee would have been injured had she not been present in the workplace - in other words, under positional risk analysis work itself need not have increased the risk of injury beyond that faced by a member of the general public. It is sufficient that the injury results from a risk that was in fact produced in the workplace. Under either "arising out of" rule, as certain celebrated commentators have put it, "the requisite causal nexus between injury and employment is not to be measured by common law tort standards and ... it is sufficient that the employment was a contributing cause." 14 Workers' compensation was, in short, meant to be easier to prove than tort causation.

Then an interesting thing happened. Causation in torts cases involving occupational diseases became in some ways easier to establish. The story is too long to tell here, but many readers will be generally familiar with the story of "toxic torts" and sprawling asbestos litigation. ${ }^{15}$ The "but for" causation standard had been difficult for plaintiffs to meet in toxic tort cases alleging that negligent defendants caused their disease. Often toxic tort plaintiffs experienced multiple exposures to a single substance thought to cause a particular disease (whether exposed inside or outside of the workplace), or were exposed to a variety of such substances (inside or outside of the workplace), each exposure potentially being responsible for causing the disease. Thus, even if the plaintiff could establish that a defendant negligently exposed her to a disease-causing substance, it was extremely difficult for her to show that, "but for" the defendant's negligence, she would not have contracted the disease in question. In the words of a recent article in the Journal of Occupational and Environmental Medicine:

Epidemiological evidence establishing that a risk factor is generally capable of causing the plaintiff's adverse health outcome is insufficient evidence that an individual's adverse health consequence was specifically caused by the exposures of interest. For example, evidence of an inadvertent chemical release into the ecosystem, coupled with epidemiological evidence of a causal association between such chemicals and the subject disease, is insufficient evidence that the release caused an adverse health consequence, absent evidence that the individual was exposed to a sufficient magnitude of exposure to the chemical to cause the adverse health effect; the temporal (chronological) relationship between exposure and effect is biologically plausible; and other known and biologically plausible causes have been excluded. ${ }^{16}$ (Emphases supplied) 
Because of these difficulties in tort cases, many states relaxed tort "but for" causation in multiple cause situations (that is, multiple possible exposures to, for example, toxic substances), especially when there was evidence that each exposure to a substance was independently "sufficient" sufficient cause, was not thereafter required to rule out all other sufficient causes, as would have been the case under traditional "but for" causation). ${ }^{19}$ Some states allowed findings of causation when a defendant's negligence was merely a "substantial factor" in causing a plaintiff's injury or disease. ${ }^{20}$ Why might a state do this? It was a matter of policy. The alternative would be to let the damage caused by the disease fall on individual plaintiffs in nearly every case. Some states decided that certain diseases were probably caused by certain kinds of exposures and shifted the costs of liability to "actors" engaging in the activity causing the exposures unless the actors could prove that the plaintiffs did not contract their disease through the defendant's activity. Those actors resisted and resented (and probably still resent) being "tagged" with liability (and the associated insurance expense). From the broader society's point of view, however, the only alternative may have been to let the cost of injury and disease fall on plaintiffs who, on average, were less able to adequately insure themselves than large commercial enterprises able to pass the costs of insurance on to the consuming public.

Switching to workers' compensation disease causation standards, the standards were historically relaxed in comparison to tort causation standard. They nevertheless were not so relaxed as to "convert" employers into the absolute insurers of their employees. A workers' compensation claimant has traditionally been required to demonstrate medical causation. Although the medical causation standard may vary from state to state, a common version of it is that a claimant must show, to a reasonable medical probability, that her present incapacity for work has been medically caused (to a legally-defined extent) by work. The distinction between workers' compensation medical and legal causation has been subtle, but in a "traumatic" injury context, it may not be especially significant. In $\underline{\text { disease }}$ contexts, however, it may (as in tort) be very difficult to show that a disease has been "medically caused" (if only probably) by work, even where relaxed workers' compensation causation standards might be forgiving in the case of traumatic injuries. In short, it can be very difficult to prove that diseases “arose out of" employment.

An important corollary to the last point, however, is that the complex causation of disease renders it equally difficult to show that a disease was not caused (at least in part) by workassuming that the claimant has had some "threshold" exposure to a disease-causing substance. It follows as a matter of course that, depending upon whom the burden of proof of causation is placed (the employer or the claimant), the other party will tend to prevail. Thus, if traditional burden-of-proof-on-claimant standards of medical causation are insisted upon in very complex disease contexts, claimants will tend to "lose." If the burden of proof is shifted to employers in those contexts to prove that a disease was not caused by work, employers will tend to "lose." Optimal placing of the thumb on the scale is the policy prerogative of legislatures. Legislatures must assess industrial cost shifts (costs never go away, they shift) associated with placing the thumb on one side of the scale or the other. How thumbs have sometimes been placed 
on scales in torts cases was just discussed. Firefighters' presumptions may be thought of as the workers' compensation equivalent of that kind of policy making.

\section{Firefighter/First Responder Presumptions}

\section{A. Historical Background}

In occupational disease contexts there is workers' compensation historical precedent for legislatures placing their collective thumbs on the scale in favor of coverage. This early presumptive coverage likely began as a form of collective intuition that certain diseases were probably caused by work and that the social costs of insisting on strict proof of causation exceeded the benefits. Early American workers' compensation statutes bore a close relationship to the English/U.K. workers' compensation acts of 1897 and 1906. The U.K. Act of 1906, in particular, dealt with the problem of occupational disease by establishing a statutory "schedule" of diseases and creating a statutory presumption that, where a worker had been employed continuously for a designated period of time in a specific work process, and thereafter developed one of the listed diseases, the disease was presumed to have arisen out of employment. This "two column" approach (column one being the process, and column two being the specific scheduled, or listed, disease) is revealed in the text of the 1906 Act:

(1) Where-

(1) The certifying surgeon appointed under the Factory and Workshop Act, 1901, for the district in which a workman is employed certifies that the workman is suffering from a disease mentioned in the third schedule to this act, and is thereby disabled from earning full wages at the work at which he was employed; or

$* * * * * * * * * * * * * * * * * * *$

(3) The death of a workman is caused by any such disease and the disease is due to the nature of any employment in which the workman was employed at any time within the twelve months previous to the date of the disablement or suspension, whether under one or more employers; he or his dependents shall be entitled to compensation under this act as if the disease or such suspension as aforesaid were a personal injury by accident arising out of and in the course of that employment, subject to the following modifications:

(a) The disablement or suspension shall be treated as the happening of the accident . . . 
The diseases listed in the "Third Schedule" of the 1906 Act were anthrax, lead poisoning, mercury poisoning, phosphorous poisoning, arsenic poisoning, and Ancylostomiasis (hookworm disease). The corresponding "processes" were handling wool, using lead, mercury, phosphorous, or arsenic, and mining. If an employee contracted the disease outside of the process, he or she could try to prove causation, but the schedule (and its implicit presumptions) did not apply.

Slightly later versions of the New York and Minnesota Acts modeled the British approach more directly stated that, "If the employee, at or immediately before the date of disablement, was employed in any process mentioned in the second column of diseases ... the disease presumptively shall be deemed to have been due to the nature of the employment." ${ }^{22}$ (Emphases supplied). (It is unclear to this writer whether and how burden shifting mechanisms - see belowoperated under these early disease presumptions).

Space does not permit extended discussion of subsequent development of American occupational disease coverage. It is enough to say that all states now cover occupational disease, some through workers' compensation statutes, and others through stand-alone occupational disease statutes. ${ }^{23} \mathrm{New}$ York, in 1920, was apparently the first American state to follow the English practice of scheduling diseases. ${ }^{24}$ As the Larson's treatise notes,

While the schedule method was widely copied, the trend has been toward expansion into general coverage, either by abandoning the schedule altogether, or, as was done in New York, Ohio, and, more recently, Nevada, by leaving the list intact while saying that the act also covers all other occupational diseases. The purpose of including a description of the "process" appears to be to establish a strong presumption that the contraction of that disease by one engaged in that process was attributable to the employment, while the contraction of the same disease in another process would require definite affirmative proof of causal connection. (emphasis supplied). ${ }^{25}$ (Emphases supplied)

The practice in American law of presuming work causation of diseases when workers are engaged in certain occupational processes was, accordingly, well-established by the early decades of the $20^{\text {th }}$ century. Firefighter presumptions are consistent with that practice. As of this writing, thirty-four states appear to have enacted firefighter presumption laws of some kind ${ }^{26}$ The laws, which seem to enjoy widespread public support, continue to expand despite disputes over competing interpretations of scientific studies on the relationship between firefighting duties and development of various diseases (especially cancers) ${ }^{27}$ Overall, firefighter presumptions apply most often to cancer, lung and respiratory conditions, blood and infectious diseases, and heart and vascular conditions. ${ }^{28}$ 
Firefighter Presumptions and PTSD Coverage

NCOIL Annual Meeting, December 12, 2019

Remarks of Professor Duff

\section{B. How Firefighter Presumptions Work}

"Presumptions" have a broadly applicable legal definition, though in the narrower context of the Firefighter/First Responder presumptions their purpose is to make it easier to establish that certain diseases commonly suffered by firefighters/public safety officials/first responders are caused by work. Black's Law Dictionary defines a presumption as,

A legal inference or assumption that a fact exists because of the known or proven existence of some other fact or group of facts. - Most presumptions are rules of evidence calling for a certain result in a given case unless the adversely affected party overcomes it with other evidence. A presumption shifts the burden of production or persuasion to the opposing party, who can then attempt to overcome the presumption. ${ }^{29}$

So, given certain factual predicates - a firefighter worked continuously as a firefighter for a defined period of time and contracted a specified disease - that "group of facts" creates a legal inference that contraction of the disease was caused by the firefighter's working conditions.

The question then becomes what happens after the presumption has been created. In other words, the question becomes how the employer "can attempt to overcome the presumption." As Judge David B. Torrey has explained, ${ }^{30}$ two theories of presumptions exist. The first theory treats the presumption as procedural. Once an employer produces expert medical opinion contrary to the causation presumption - that the cancer or other disease subject to the presumption is not workrelated, the presumption disappears from the case (a classic shorthand for this type of presumption in evidence law is the "bursting bubble"). The firefighter-claimant does not lose the case outright at that point, but the "burden of production" shifts back to the claimant, who must now satisfy that burden and the overall "burden of proof" of work-relatedness/causation without the benefit of the presumption. It should be emphasized that, although "procedural," the presumption under this Thayer-Wigmore approach must still be met by the defendant with some substantial evidence: the evidence necessary to overcome the presumption must, viewed alone, disprove the nonexistence of the presumed fact. In other words, under "classical" Thayer-Wigmore analysis, in order to burst the bubble the opponent-defendant must do more than submit evidence that "tends" to disprove causation. ${ }^{31}$

The second theory of presumption, the so-called Morgan theory, treats establishment of the work-relatedness/causation presumption as evidentiary, a development which, in effect, creates a substantive rule of law. If the employer produces evidence rebutting the presumption of workrelatedness/causation, "the bubble does not burst." Rather, the presumption remains, essentially as positive evidence of causation, and, under the rules of several states, ${ }^{32}$ both the burden of production and of persuasion shift to the employer to prove that work did not cause the disease in question. It is as if creation of the presumption placed the burden of proof of non-causation 
on the employer as a matter of law. Under either theory, the presumption created remains rebuttable. ${ }^{33}$

There is a great deal of state variability as to whether Thayer or Morgan-type presumptions apply (or something state-specific that is not quite either). Some presumptions seem to fall in between the two extremes. Obviously, the presumptions are of differing strength. As the Larson's treatise notes, "[t]he best way to measure this strength is by the negative test of how much it takes to rebut or overcome the presumption," but "[t]he possible grounds for rebutting the presumption vary so widely that the end product varies from a virtually irrebuttable to a virtually worthless presumption." ${ }^{34}$ This paper will not undertake to survey the variety of the presumptions but will mention Judge Torrey's contention that, "[m]ost states seem to treat the firefighter cancer presumption under the Morgan approach," and his identification of Virginia, Maryland, Oregon, North Dakota, Missouri, and Colorado as states falling into the Morgan camp. ${ }^{35}$ Morgan-type presumptions would tend to be strongest, with the absolute strongest variety requiring employers to prove not only that the disease was not caused by the work in question, but also that there was a specific non-occupational cause. ${ }^{36}$ One of the more noteworthy litigation issues concerning presumptions is the struggle over whether defendants may attempt to argue against them. In other words, defendants sometimes attempt not to overcome presumptions-by, for example, arguing about the tobacco usage of a particular plaintiff — but rather to assert that the presumptions themselves are scientifically unsound. These arguments are often poorly received by courts. ${ }^{37}$

State statutes with Firefighter/First Responder presumptions typically impose threshold eligibility criteria. Texas, for example, houses the "firefighter presumption" in Title 6 of its Government Code. The relevant statutory criteria ${ }^{38}$ provide that the presumption:

- applies only to a firefighter, peace officer, or emergency medical technician

- who, upon becoming employed in that position received a physical examination that failed to reveal evidence of the illness or disease for which benefits or compensation are sought;

- The employee in the relevant classification must have been employed for five or more years in that classification before the presumption applies;

- The employee must seek benefits or compensation for a disease or illness covered by the law that is discovered during employment in the classification.

- The diseases covered by the law are

- cancer that originates at the stomach, colon, rectum, skin, prostate, testis, or brain

○ non-Hodgkin's lymphoma

○ multiple myeloma

$\bigcirc$ malignant melanoma

- renal cell carcinoma 
Firefighter Presumptions and PTSD Coverage

NCOIL Annual Meeting, December 12, 2019

Remarks of Professor Duff

Most states with firefighter presumptions possess similar criteria.

\section{Post-Traumatic Stress Disorder}

Post-traumatic stress disorder (PTSD) is "a psychiatric disorder that can occur in people who have experienced or witnessed a traumatic event such as a natural disaster, a serious accident, a terrorist act, war/combat, rape or other violent personal assault." ${ }^{, 39}$ Furthermore,

[p]eople with PTSD have intense, disturbing thoughts and feelings related to their experience that last long after the traumatic event has ended. They may relive the event through flashbacks or nightmares; they may feel sadness, fear or anger; and they may feel detached or estranged from other people. People with PTSD may avoid situations or people that remind them of the traumatic event, and they may have strong negative reactions to something as ordinary as a loud noise or an accidental touch. ${ }^{40}$

Thus, PTSD can be generally disabling and, if sufficiently intense, could obviously create work incapacity. Moreover, given the potential connection of PTSD to a specific, unexpected work event, it would theoretically be consistent with the concept of an "accident" depending on the circumstances in which it arose. But there are at least two doctrinal workers' compensation complications. First, it is also possible to imagine PTSD resulting from a series of severe traumatic events. In those circumstances, it would be harder to think of the condition as the product of an "accident," just as accidents are difficult to establish in other types of "cumulative" injury contexts. Along these lines, Washington is an example of a state appearing to cover PTSD under workers' compensation if it is the product of a single acute event (more accident-like), but not if it is caused by a series of traumatic events. ${ }^{41}$ (It is, of course, possible to classify PTSD as an occupational disease where a state possesses a standalone statute).

A second complication is that PTSD may, under given statutory definitions, be classified as a "mental" injury brought on by strictly "mental" stimuli-what is sometimes known in the workers' compensation lexicon as a "mental-mental" injury. (PTSD could also "parasitically" develop from physical injury ("physical-mental"- - think depression following a long-term back injury), and there seems far less resistance to covering the condition in such circumstances). ${ }^{42}$

The Larson's treatise notes: "there is already visible an impressive majority position supporting compensability in these [mental-mental] cases." 43 Compensability for mental-mental injuries is not universal, however (there has historically been a significant minority position supporting non-coverage of such injuries), and can be controversial. The argument for coverage took quite some time to develop doctrinally. ${ }^{44}$ This makes sense when one considers that the analogous tort action of negligent infliction of emotional distress ${ }^{45}$ (NIED) was in its infancy in the early $20^{\text {th }}$ century, when the quid pro quo of workers' compensation for tort originated. ${ }^{46}$ The majority position at that time was that an NIED tort remedy, when available, required some negligent physical impact with the plaintiff"s body (the "impact theory") to allow for any claim of 
emotional distress. ${ }^{47}$ In historical context, negligently caused emotional injuries were probably not (or only dimly) conceived as encompassed by the Grand Bargain.

Once NIED actions became broadly viable in tort law (especially through increased use of the "zone of danger" test),${ }^{48}$ the risk of tort liability for negligently caused emotional injury in the workplace also became more "real." ${ }^{49}$ As already discussed, with the genesis of tort liability comes the demand for tort-immunity, and hence the expansion of mental-mental claims to which Larson's refers. ${ }^{50}$ Then, once "mental-mental" workers' compensation claims become viable, it is conceptually difficult to exclude coverage of PTSD claims, particularly those of public safety officials and first responders exposed to extraordinary, accident-like events while serving in the public interest.

As commentators note,

All 50 states and the District of Columbia specifically address WC compensability for mental-mental and mental-physical injuries, either by statute, regulation, and/or case law. WC laws vary greatly across the country, with approximately half of the jurisdictions allowing compensation for mental-mental injuries or illnesses under limited circumstances. Compensable mental-mental injuries must typically be considered extraordinary and the predominant or substantially contributing cause. Other jurisdictions generally allow for compensability only for mental-physical injuries. ${ }^{51}$

This writer has surveyed current law and it appears that, as of this writing, twelve states address PTSD explicitly by statute. ${ }^{52}$ Other states appear to address PTSD, as a practical matter, through general statutory provisions governing mental or emotional injury. The National Council on Compensation Insurance reports that,

In 2019, at least 26 states considered legislation addressing workers compensation coverage for mental-only injuries, such as PTSD, for first responders. To date, eight states (Connecticut, Idaho, Louisiana, Nevada, New Hampshire, New Mexico, Oregon, and Texas) passed legislation addressing benefits for first responders with PTSD in 2019. In addition, Utah passed legislation establishing a working group to study the compensability of mental stress claims from first responders..$^{53}$

Of special mention in this area are the current statutes of Vermont and New Hampshire, which appear to have established PTSD causation presumptions for first responders.

The Vermont statutory language reads:

In the case of police officers, rescue or ambulance workers, or firefighters, posttraumatic stress disorder that is diagnosed by a mental health professional shall be presumed to have been incurred during service in the line of duty and shall be compensable, unless it is shown by a preponderance of the evidence that the post- 
Firefighter Presumptions and PTSD Coverage

NCOIL Annual Meeting, December 12, 2019

Remarks of Professor Duff

traumatic stress disorder was caused by nonservice-connected risk factors or nonservice-connected exposure. ${ }^{54}$ (Emphasis supplied)

New Hampshire law provides:

Notwithstanding RSA 281-A:2, XI [defining accidental injury] and XIII [defining occupational disease], RSA 281-A:16 [defining dates of injury], and RSA 281-A:27 [death benefit payments], there shall be a prima facie presumption that acute stress disorder and post-traumatic stress disorder in an emergency responder, as defined [by statute] are occupationally caused. ${ }^{55}$ (Emphasis supplied)

\section{Conclusion}

The expansion of firefighter causation presumptions and the deepening coverage of PTSD or other mental/emotional/psychological injuries appear to spring from a growing public consensus that first responders must be adequately compensated for diseases that are arguably related to their work. The expansion may also spring from the avoidance of tort liability, which remains plausible under state torts claims acts. In either event, the expanded workers' compensation coverage comes at a cost, and it may at times appear that workers' compensation is an awkward vehicle for providing the coverage. But the awkwardness of compensating for occupational disease is hardly new: disease has always been complex and difficult to ascribe with precision to work. The day may come when legislatures will learn definitively that certain covered diseases are not caused by work, and on that day coverage may be reconsidered. But until that day comes, there seems to this observer compelling reasons to remedy occupational disease in any way reasonably possible. The alternative seems too terrible to contemplate.

\footnotetext{
${ }^{1}$ See my related commentary at https://lawprofessors.typepad.com/workerscomplaw/2018/08/thinking-clearly-aboutthe-quid-pro-quo.html

${ }^{2}$ See generally Michael C. Duff, How the U.S. Supreme Court Deemed the Workers' Compensation Grand Bargain “Adequate” Without Defining Adequacy, 54 TulsA L. REV. 375 (2019)

${ }^{3} 1911$ NATIONAL InSURANCE ACt, SpARTACUS EDUCATIONAL available at https://spartacuseducational.com/Linsurance1911.htm

${ }^{4}$ Duff, How the U.S. Supreme Court Deemed the Workers' Compensation Grand Bargain "Adequate"

5 John Fabian Witt, The Accidental Republic: Crippled Workingmen, Destitute Widows, and the REMAKING OF AMERICAN LAW 9, 10 (2004).
} 
Firefighter Presumptions and PTSD Coverage

NCOIL Annual Meeting, December 12, 2019

Remarks of Professor Duff

${ }^{6}$ New York Central R. Co. v. White, 243 U.S. 188 (1917)

${ }^{7}$ The National Academy of Social Insurance estimates that as of 2017 workers' compensation coverage extended to 97.5\% non-federal jobs covered by unemployment insurance and $86.8 \%$ of all jobs in the U.S. WORKERS' COMPENSATION: BENEFITS, CoSTS, AND COVERAGE, NATIONAL ACADEMY OF SOCIAL INSURANCE 12 (October 2019) available at https://www.nasi.org/sites/default/files/nasiRptWkrsComp201710_31\%20final(1).pdf

${ }^{8} \mathrm{An}$ accident is most easily conceived as an unexpected event occurring at a particular time. See generally 3 LARSON'S WORKERS' COMPENSATION LAW $§ 42.01$. Massachusetts is an example of a state that has not had an explicit accident requirement. The classic early example of the inadvisability of an accident requirement was of a "workman" becoming blind from various occupational exposures over a period of time. See e.g. In re Hurle, 217 Mass. 223, 104 N. E. 336 (1914)

${ }^{9}$ This paper will discuss "arising out of" rather than "in the course of" difficulties. The writer understands, however, that many arising out of problems also may present "in the course of" problems.

${ }^{10}$ See supra., n.8

${ }^{11}$ As the Larson's treatise notes, coverage was easier in Massachusetts because it never had an accident requirement in its law. 4 LARSON'S WORKERS' COMPENSATION LAW $§ 52.02$

${ }^{12}$ SOMERS \& SOMERS, WorkMEN's COMPENSATION, John Wiley \& Sons 49-50 (1954)

${ }^{13}$ As Somers and Somers recount, proponents of disease coverage pointed out very early in the history of workers' compensation that accidents and diseases tended to merge with each other to the point where they cannot be distinguished from each other; and, in any event, employers are in the best position to implement preventive measures and the workers' compensation premium can serve as an incentive to do so. $I d$. at 49

${ }^{14}$ SOMERS \& SOMERS, WORKMEN'S COMPENSATION, supra. at 54

${ }^{15}$ GoldBerg, SEboK, \& ZiPURSKy, ToRT LAW: ResponsibILITIES AND REDRESS 280-283 (Wolters Kluwer, $4^{\text {th }}$ ed. 2016)

${ }^{16}$ William W. Greaves, MD, MSPH, Rajiv Das, MD, MPH, MS, Judith Green McKenzie, MD, MPH, Donald C. Sinclair II, JD, and Kurt T. Hegmann, MD, MPH, PRACTICE GuIDELINES: WORK-RELATEDNESS, JOEM Volume 60, Number 12, December 2018 available at https://acoem.org/acoem/media/News-Library/JOEM-Work-relatednessDec-2018.pdf 
Firefighter Presumptions and PTSD Coverage

NCOIL Annual Meeting, December 12, 2019

Remarks of Professor Duff

${ }^{17}$ RESTATEMENT (THIRD) OF TORTS $§ 27, \mathrm{cmt}$. c

${ }^{18}$ GOLDBERG, et al., TORT LAW at 260-287

${ }^{19}$ For a spirited defense of the "but for" standard see Torey A. Weigand, The Wrongful Demise of But For Causation,

41 W. NEW ENG. L. REV. 75 (2019), https://digitalcommons.law.wne.edu/lawreview/vol41/iss1/4/

${ }^{20}$ Virginia specifically rejected this approach, and for an illustrative case discussing these developments see Ford Motor Co. v. Boomer, 736 S.E. 2d 724 (Va. 2013)

${ }^{21}$ British Workers' Compensation Act of 1906, 6 Edw. VII, c. 58, Section 8

${ }^{22}$ WALTER F. DOdD, AdMINISTRATION OF WORKERS' COMPENSATION 768 (1936)

234 LARSON'S WORKERS' COMPENSATION LAW $§ 52.01$

244 LARSON'S WORKERS' COMPENSATION LAW $§ 52.02$

${ }^{25} I d$.

${ }^{26}$ IAFF FIREFIGHTERS, Winning and Improving Presumption Laws, available at http://client.prod.iaff.org/\#contentid=48598; see also Fawn Racicot and Bruce Spidell, Presumptive Coverage for Firefighters and Other First Responders, NATIONAL COUNCIL ON COMPENSATION INSURANCE RESEARCH BRIEF (November 2018) available at https://www.ncci.com/Articles/Documents/Insights-Research-Brief-PresumptiveCoverage.pdf; FIRST RESPONDER CENTER FOR EXCELLENCE,Presumptive Legislation for Firefighter Cancer available at https://www.firstrespondercenter.org/cancer/toolsresources/presumptive-legislation-firefighter-cancer-state/; see also Racicot and Spidell, NCCI, Presumptive Coverage for Firefighters at 3

${ }^{27}$ See InTERnAtional Association OF Fire CHIEFs, REVIEW OF THE NLC'S Assessing StATE FiREFiGHTER CANCER PRESUMPTION LAWS available at https://www.iafc.org/topics-and-tools/resources/resource/review-of-nlc-assessingstate-firefighter-cancer-presumption-laws

${ }^{28}$ Racicot and Spidell, NCCI, Presumptive Coverage for Firefighters at 3-6

${ }^{29}$ BLACK’S LAW DiCTIONARY (11th ed. 2019)

${ }^{30}$ David B. Torrey, Firefighter Cancer Presumption Statutes In Workers' Compensation and Related Laws: An Introduction And A Statutory/Regulatory/Case Law Table in PENNSYLVANIA BAR ASSOCIATION WORKERS' COMPEnSATION LAW SEction Newsletter (Volume VII, No. 116, November 2013) (hereinafter ToRREy, FIREFIGHTER CANCER PRESUMPTIONS) 
Firefighter Presumptions and PTSD Coverage

NCOIL Annual Meeting, December 12, 2019

Remarks of Professor Duff

${ }^{31}$ See generally Christopher B. Mueller \& Laird C. Kirkpatrick, 1 Federal Evidence § 3:10 (4th ed. 2019)

324 LARSON'S WORKERS' COMPENSATION LAW § 52.07 [2] [a] [iii]

${ }^{33}$ Judge Torrey has argued that an irrebuttable presumption may be unconstitutional. Id. at 35 . That may be true as a matter of state constitutional law (e.g., North Carolina which once struck down a Heart Statute as an unconstitutional special law, Duncan v. Charlotte, 234 N.C. 86 (1951)), but one may doubt it is true as a matter on federal constitutional law given the current limitations of the $14^{\text {th }}$ amendment.

344 LARSON'S WORKERS' COMPENSATION LAW $§ 52.07$

${ }^{35}$ Torrey, supra., Firefighter Cancer Presumption Statutes at 41

364 LARSON'S WORKERS' COMPENSATION LAW § 52.07 [2] [a] [i], [ii]

${ }^{37}$ City of Frederick v. Shankle, 367 Md. 5, 785 A.2d 749 (Md. 2001); Linnell v. City of St. Louis Park, 305 N.W.2d 599 (Minn. 1981); Robertson v. North Dakota Workers Compensation Bureau, 616 N.W.2d 844, 855 (N.D. 2000); Medlin v. County of Henrico Police, 542 S.E.2d 33 (Va. 2001)

${ }^{38}$ V.T.C.A., Government Code $\S 607.052$

${ }^{39}$ As defined by the AMERICAN PSYCHIATRIC ASSOCIATION available at https://www.psychiatry.org/patientsfamilies/ptsd/what-is-ptsd

${ }^{40} I d$.

${ }^{41}$ See WA ADC 296-14-300(2)

${ }^{42}$ The Larson's treatise states: . . " "when there has been a physical accident or trauma, and claimant's disability is increased or prolonged by traumatic neurosis, conversion hysteria, or hysterical paralysis, it is now uniformly held that the full disability including the effects of the neurosis is compensable. Dozens of cases, involving almost every conceivable kind of neurotic, psychotic, psychosomatic, depressive, or hysterical symptom, functional overlay, or personality disorder, have accepted this rule.” 4 LARSON'S WORKERS' COMPENSATION LAW $\S 56.03$. My recent research in December 2019 has reconfirmed this generalization.

434 LARSON'S WORKERS' COMPENSATION LAW $§ 56.04$

${ }^{44}$ A full discussion of the development is beyond the scope of this paper but a compact summary can be found in 4 LARSON'S WORKERS' COMPENSATION LAW $§ 56.04$ [1] 
Firefighter Presumptions and PTSD Coverage

NCOIL Annual Meeting, December 12, 2019

Remarks of Professor Duff

45 "The tort of causing another severe emotional distress through one's negligent conduct. Most courts will allow a plaintiff to recover damages for emotional distress if the defendant's conduct results in physical contact with the plaintiff or, when no contact occurs, if the plaintiff is in the zone of danger." BLACK's LAW DICTIONARY (11 ${ }^{\text {th }}$ ed. 2019)

${ }^{46}$ See e.g. Wyman v Leavitt, 71 Me. 227, 230 (1880) (“... we have been unable to find any decided case, which holds that mental suffering alone, unattended by any injury to the person, caused by simple actionable negligence, can sustain an action.”).

${ }^{47}$ See Consolidated Rail Corp. v. Gottshall, 512 U.S. 532 (1994) (explaining the slow progress of NIED during the period contemporaneous with enactment of FELA, which was roughly the same [1908] as reception of workers' compensation statutes)

${ }^{48}$ Under the zone of danger test a plaintiff may recover for purely emotional injury if placed in fear of harm while located in a place, or "zone," where physical harm is reasonably foreseeable. The zone of danger is also broadly applied in instances of "bystander" actions. RESTATEMENT THIRD OF TORTS $§ 48$ (2012) (29 jurisdictions recognize bystander liability for closely related persons).

${ }^{49}$ In my home state of Wyoming, for example, the Wyoming Supreme Court found, in Collins v. COP Wyoming, 126 P.3d 886 (Wyo. 2006), that an employee unable to bring a mental-mental workers' compensation claim could bring a negligent infliction of emotional distress action against his employer; categorical exclusion from a workers' compensation remedy deprived the employer of worker's compensation immunity. Otherwise, the worker would have been left with no remedy, triggering constitutional concerns.

${ }^{50}$ Compare the Larson's treatise position that almost the identical dynamic was at play in occupational diseases generally. 4 LARSON'S WORKERS' COMPENSATION LAW $§ 52.02$

${ }^{51}$ Bruce Spidell, Post Traumatic Stress Disorder in Workers' Compensation, NATIONAL CounCIL ON COMPENSATION INSURANCE available at https://www.ncci.com/Articles/Pages/II_Insights-PTSD-Injuries.aspx

${ }^{52}$ California (CA LABOR § 3212.15)[domestic terrorism]; Colorado (CO ST § 8-41-301(3)); Connecticut (CT ST § 31-275(16)(B)(3)); Idaho (ID ST § 72-451); Maine (39-A §201(3-A)(B)); Minnesota (MN ST § 176.011 Subd,. 15(d)); Nebraska (48-101.01); New Hampshire (NH ST § 281-A:2); Oregon (OR ST § 656.802(7)(a) \& (b)); Texas (Sec. 504.019); Vermont (VT. STAT. § 601(11)(I)(i)); and Washington (WA ADC 296-14-300(2)) 
Firefighter Presumptions and PTSD Coverage

NCOIL Annual Meeting, December 12, 2019

Remarks of Professor Duff

${ }^{53}$ NCCI, Regulatory and Legislative Trends Report (2019) available at ncci.com/Articles/Documents/II_RegulatoryLegislative-Trends2019.pdf.

${ }^{54} 21$ V.S.A. $§ 601$ (I)(i)

${ }^{55}$ N.H. Rev. Stat. § 281-A:17-c 